in order to obtain its specific activity. To ascertain that the radioactive glycine was not carried through the extraction, controls were run in which the trichloroacetic acid containing the inert glutathione was added before incubation.

In Table I, the radioactivity of the mercaptide extracted from the cells incubated in the basal medium is taken as 100 . The incorporation of ${ }^{14} \mathrm{C}$ carboxyl labeled glycine into the glutathione of yeast is similar to the uptake of labeled glycine into the "protein fraction" of yeast in that both reactions are inhibited by cyanide, anaerobic conditions, lyophilization, and grinding of the cells ${ }^{2}$. (To rule out inhibition by carborundum or its contaminants, cells to which the carborundum was added but which were not ground were also incubated.) Likewise, both reactions are slightly inhibited by the omission of $\mathrm{MgSO}_{4}$, and enhanced by an $\mathrm{O}_{2}$ atmosphere. The omission of glucose or $\mathrm{CaCl}_{2}$, however, is without effect on the glutathione synthesis by yeast while the omission of either of these two substances causes pronounced inhibition on the incorporation of labeled glycine into the "protein fraction".

BLOCH in a series of eight experiments in which labeled glutathione formation in the presence of $\mathrm{O}_{2}$ and $\mathrm{N}_{2}$ was compared, found that the average value for anaerobic synthesis was $\mathrm{I} \%$ of that found under aerobic conditions ${ }^{3}$. This investigator also reported that the omission of cysteine or glutamic acid significantly decreased the rate of the reaction. In our experiments on yeast, these amino acids are equally effective.

JOHNSTON AND BLOCH observed that adenosine triphosphate markedly accelerated the aerobic synthesis of glutathione in liver homogenates. By adding adenosine triphosphate to the cellular debris resuspended in BLOCH's medium the synthetic activity may be slightly restored.

\title{
REFERENCES
}

1 H. WAelsch And D. Rittenberg, J. Biol. Chem., I39 (194I) 76 I.

2 F. FriedberG and A. H. WebB, J. Bact., 58 (I949) I 5 I.

${ }^{3}$ K. Bloch, J. Biol. Chem., I 79 (I949) 1245 .

4 R. B. Johnston and K. Bloch, J, Biol. Chem., 79 (I949) 493.

Received May I 2 th, I952

\section{THE INFLUENCE OF ACETATE ON THE FERMENTATION}

\section{OF BAKERS'. YEAST}

\author{
by \\ TH. J. M. MAESEN AND E. LAKO \\ Laboratory for Physiological Chemistry, The University, Utrecht (Netherlands)
}

In experiments on the stimulation of the anaerobic fermentation of bakers' yeast* by thiamine and ammonium ions it became necessary also to investigate the influence of the $\mathrm{pH}$ of the medium.

Living yeast cells suspended in $0.068 \mathrm{M}$ sodium acetate solution at $\mathrm{pH} 5.6$ ferment glucose with constant and high velocity during several hours. At $\mathrm{pH} 3.5$ the fermentation rate is equally constant, but very low.

Table I shows that with sodium acetate concentrations between o.or 7 and $0.034 M$ at $\mathrm{pH} 3.5$ the fermentation rate is about inversely proportional to the concentration. At $\mathrm{pH} 5.6$ increase of the concentration of sodium acetate causes a weak stimulation instead of an inhibition.

Because at $\mathrm{pH} 3.5$ the undissociated acetic acid molecule is the only component of the solution which is present in a reasonable quantity, whereas at $\mathrm{pH} 5.6$ sodium and acetate ions are the dominating components, it seemed likely that the inhibition of fermentation at $\mathrm{pH} 3.5$ must be attributed to the undissociated acetic acid molecule. That this is indeed true could be demonstrated by replacing the acetate by a succinate solution (Table II).

So far the experiments give no answer to the question whether the observed low rate of fermentation in acetate medium at $\mathrm{pH} 3.5$ is due to a change of internal $\mathrm{pH}$ or to a "toxic" influence of acetate ions within the cell.

\footnotetext{
" "Koningsgist" from the "Nederlandse Gist- en Spiritusfabriek", Delft (Netherlands).
} 
TABLE I

INFLUENCE OF ACETATE ON THE FERMENTATION RATE AT pH 3.5 AND 5.6

$13.4 \mathrm{mg}$ fresh yeast per Warburg vessel; $2.5 \%$ glucose; various concentrations of sodium acetate; temp. $27^{\circ} \mathrm{C}$; gas phase: $\mathrm{N}_{2}$. Each run made in triplicate and the fermentation followed for 3 hours. Number of experiments: 8 at $\mathrm{pH} 3.5$ and 5 at $\mathrm{pH}$ 5.6. Fermentation rate expressed in $\mathrm{mm}^{3} \mathrm{CO}_{2}$ per 20 minutes)

\begin{tabular}{cccc}
$\begin{array}{c}\text { Concentration } \\
\text { of sodium acetate: }\end{array}$ & $0.068 M$ & $0.034 M$ & $0.017 M$ \\
\hline $\begin{array}{c}\text { Fermentation rate } \\
\text { at } \mathrm{pH} 3.5\end{array}$ & $10 \pm 0.8$ & $27 \pm 0.9$ & $54 \pm 0.6^{\star}$ \\
at $\mathrm{pH} 5.6$ & $75 \pm 2.0$ & $66 \pm 1.3$ & $62 \pm 0.6$ \\
\hline
\end{tabular}

* Standard deviation of the mean.

TABLE II

COMPARISON OF THE FERMENTATION RATES IN ACETATE AND SUCCINATE AT pH 3.5 AND 5.6

(Concentrations of acetate and succinate $0.068 M$ in all cases. At $\mathrm{pH} 3.50 .054 M$ NaCl added to bring the concentration of sodium ions at this $\mathrm{pH}$ to that obtaining at $\mathrm{pH} 5.6$. Further conditions of fermentation as in Table I. Fermentation rate expressed in $\mathrm{mm}^{3} \mathrm{CO}_{2}$ per 20 minutes)

\begin{tabular}{|c|c|c|c|c|}
\hline \multirow{2}{*}{$\begin{array}{c}\text { Experiment } \\
\text { no. }\end{array}$} & \multicolumn{2}{|c|}{ Succinate } & \multicolumn{2}{|c|}{ Acetate } \\
\hline & $p H 3.5$ & pH 5.6 & $p H_{3 \cdot 5}$ & $p H 5.6$ \\
\hline I & 66 & 65 & - & - \\
\hline 2 & 63 & $5^{6}$ & 12 & 68 \\
\hline
\end{tabular}

TABLE III

INFLUENCE OF SODIUM AND ACETATE IONS ON THE FERMENTATION RATE AT pH 5.6

(In column $20.045 M \mathrm{NaCl}$ added to bring the concentration of sodium ions in this column to that obtaining in column 3. Further conditions of fermentation as in Table I. Number of experiments: 7)

\begin{tabular}{lccc}
\hline $\begin{array}{c}\text { Concentration } \\
\text { of sodium acetate: }\end{array}$ & $0.0 \mathrm{I} 7 \mathrm{M}$ & $\begin{array}{l}0.0 \mathrm{r} \mathrm{M} \\
+\mathrm{NaCl}\end{array}$ & $0.068 \mathrm{M}$ \\
\hline $\mathrm{mm}^{3} \mathrm{CO}_{2}$ per $20 \mathrm{~min}$ & $57 \pm \mathrm{I} . \mathrm{I}$ & $6 \mathrm{I} \pm 0.8$ & $70 \pm \mathrm{I} .6^{\star}$ \\
\hline
\end{tabular}

* Standard deviation of the mean.

The following observations are in favour of the first possibility: (a) if the inhibition by the acetic acid is not too high it can be completely abolished by the addition of a small quantity of potassium ions to the medium (cation exchange ${ }^{1}$ ); (b) the weak stimulation at $\mathrm{pH} 5.6$ by sodium acetate solution is mainly due to the acetate ions (Table III).

The fact that no difference in fermentation rate was observed between $\mathrm{pH} 3.5$ and 5.6 in succinate medium might appear to be in contradiction with this view. According to CoNWAY AND DownEx ${ }^{2}$, however, succinate acid only penetrates into the "outer region" of the yeast cell but not into the inner part of the cell. Acetic acid, on the contrary, was shown by these authors to enter freely in to both regions.

We are deeply indebted to Prof. Dr H. G. K. Westenbrink for his kind interest in our work, and to the Netherlands Organisation for Pure Scientific Research (Z.W.O.) for grants which have supported it financially. Full details and discussions will be published elsewhere.

\section{REFERENCES}

1 See $e . g$. E. J. Conway and E. O'Malley, Biochem. J., 40 (1946) 59;

A. Rothstein and L. H. Enns, J. Cell. Comp. Physiol., 28 (I946) 22 ;

E. J. Conway and T. G. Brady, Biochem. J., 47 (I950) 360.

2 E. J. Conway and Mary Downey, Biochem. $J, 47$ (1950) 347 and 355 . 